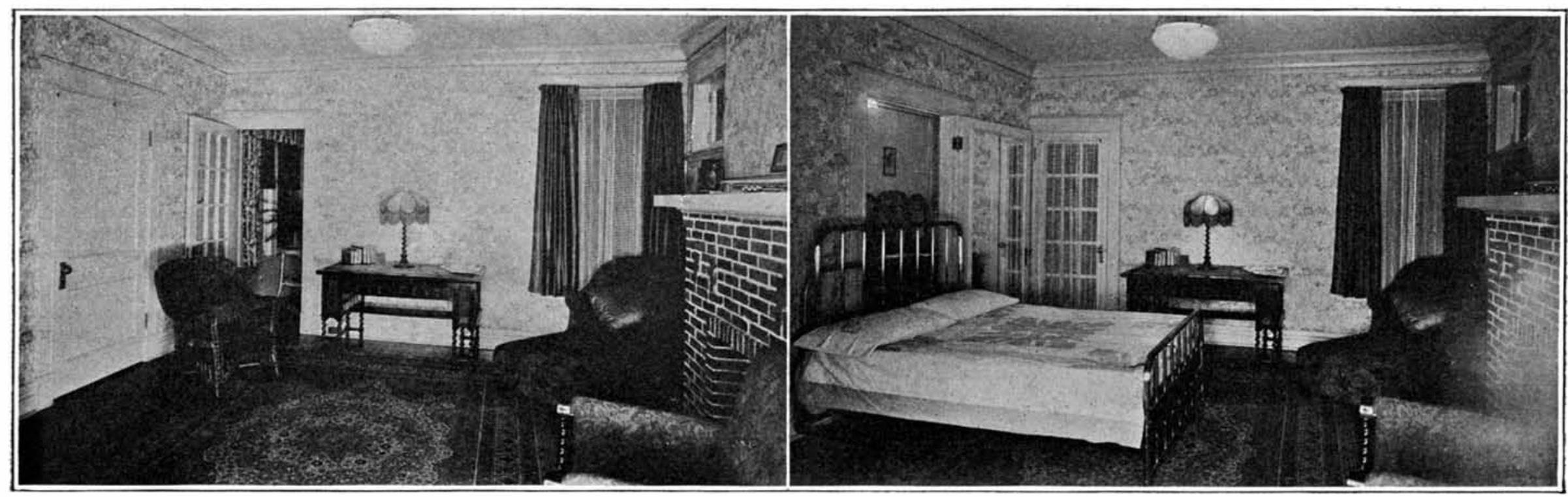

The modern living room as seen during the day and at night. The big double bed, with the bedding in place, swings upright and then, on a pivot, swings into the closet

\title{
Home Building Simplified
}

What Inventors Are Doing by Way of Giving the Home Builder More House for Less Money

By M. A. Henry A $\begin{aligned} & \text { NEW YORK real estate operator was influenced } \\ & \text { by the active propaganda for relief from the hous }\end{aligned}$ ing shortage to attempt, not so long ago, to help in his small way to provide needed homes. He secured a tract of land desirably located, and erected on it a group of six-room houses. The houses were of substantial construction-not elaborate, but with pleasing detail-and were just the sort of houses that the average American were just the sort

family longs for.
In due time they were finished and advertised. Many came to see them, but few bought. The operator was entirely at a loss to know the reason. The houses sold for $\$ 15,000$ each, at only a fair profit over their cost; they were ideally suited to the average need; the people who came to see them appeared to be the sort of people he expected to find as customers. The operator apreed to carry a cood portion of the cost on mortgage. What could be the trouble? He asked one mortgage. What could be the trouble? He asked one
of his prospective customers who had just decided of his prospective customers who had just decided
"not to buy at this time," why the prospective cus"not to buy at this time," why
tomer had reached that decision.

The man took from his pocket an envelope on the back of which he had scratched some figures.

"There's the reason you can't sell your houses," he said. "Let me explain. In the first place, whether I pay cash or part cash, there is chargeable against my. investment at least six per cent interest on $\$ 15,000$. That is $\$ 900$ a year. Then there are taxes, which at $\$ 2.81$ per $\$ 100$ on a valuation of $\$ 12,000$ is $\$ 337.20$. There is $\$ 25$ insurance a year; $\$ 150$ for coal, $\$ 200$ for repairs, and figuring the life of the house at 20 years-a it would be out-of-date and worth little then even if in good condition-the amortization charge each zear

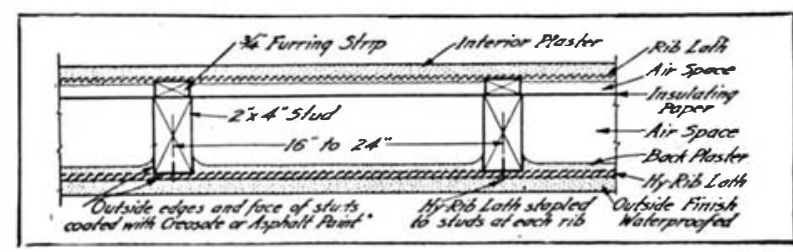

A form of wall construction which is recommended by the Bureau of Standards

is $\$ 750$. Add it up. That's a yearly cost to me of $\$ 2,362.20$-nearly $\$ 200$ a month 'rent' or about $\$ 33$ a room! I can't afford to pay $\$ 200$ a month rent and I can't afford to buy that house."

And there's the whole "housing problem" in a nut-

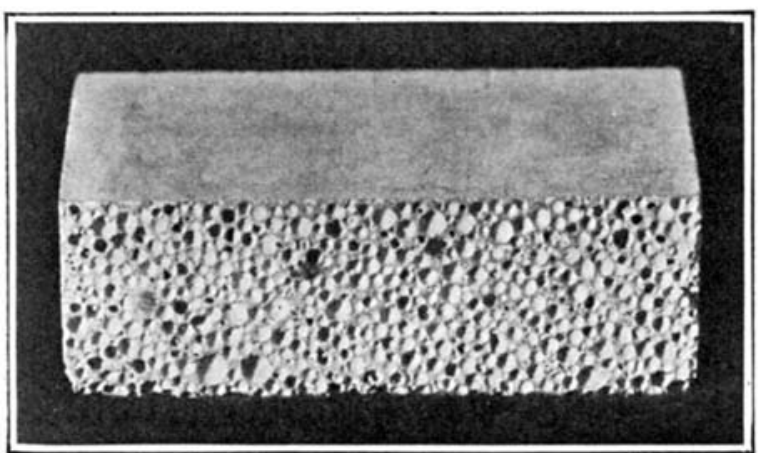

Section of a porous cement slab that is used in much the same manner as wood

for outside facings shell, so far as the individual is concerned. The American family of which the prospective customer was the spokesman, six years ago would have thought they required a six-room house for comfortable existence. Now they live in "three rooms and bath," and like it! They have a feeling they ought to be paying for their own home instead of "enriching" a landlord like the rest of the sixty per cent of our population, and they are not quite weaned away from the good old days of low building costs

But, as a matter of fact, living conditions have undergone a revolution in the past few years. To be sure, there are fewer houses per unit of population than there used to be, and the result is that in many cases two or three families are living where one lived before. But the author doubts if we are any less comfortable: we are simply learning to use our home space more economically.

That state of affairs has led to a real challenge to inventive genius to produce devices which would utilize still more efficiently the space in a small home. Just as any challenge to ingenuity calls forth much wasted effort, so we have been deluged of late with countless housing schemes and devices. A few have stood the test. It is the purpose here to show how these are actually changing our former plan of daily existen

Take the case of the man who could not affo ix six-room home. He lives in a three-room apartment at just half the cost to him of owning his own home. And those three rooms do the duty of six, because no part of the home is allowed to be idle. There is a comfortable living room with a fireplace, with no hint throughout the day that the two doors at one side conceal twin beds. These beds-full sized, substantial

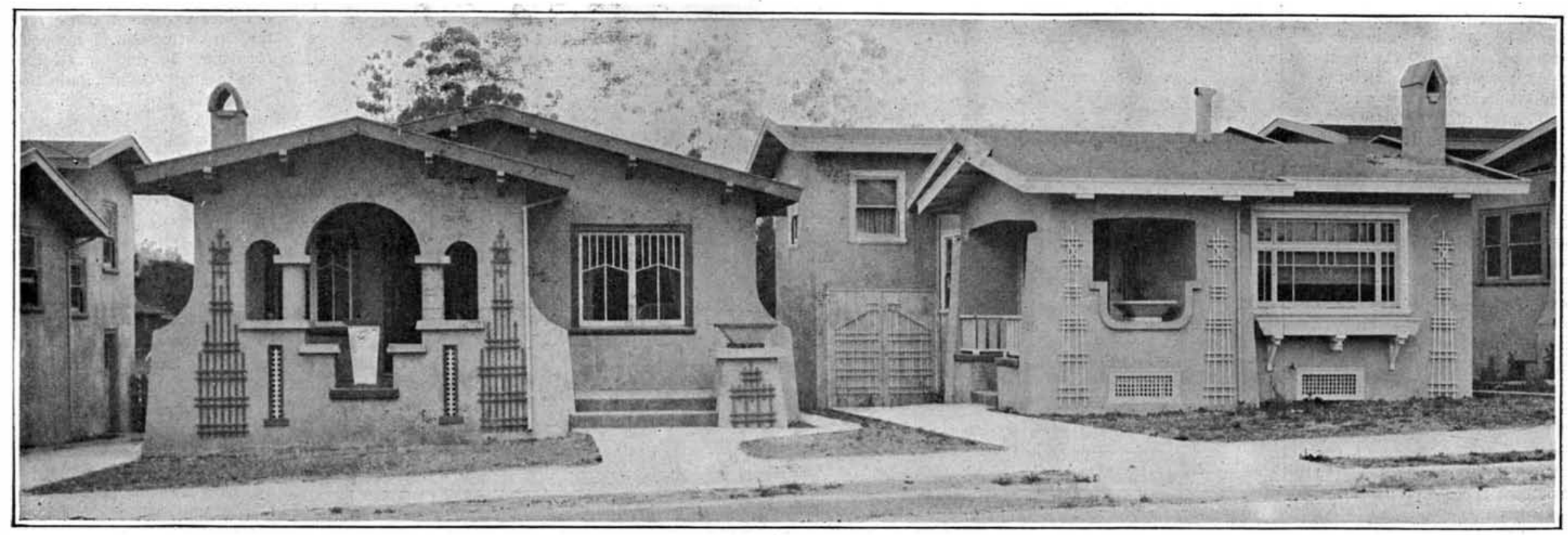

Small cottages built at Oakland, California, with all manner of space-saving devices, in order to reduce costs to a minimum 
and comfortable, fold into an upright position with the bed clothes in place, and swing on pivots into closets behind the doors. They are swung out again and lowered, ready for use, in a few seconds.

In the dining room another larger bed is concealed in another closet. The kitchen is smaller than our mothers were accustomed to, but is much more conveniently arranged and the housewife's work is considerably easier. There is no need for a servant. At one end of the kitchen is a built-in "Pullman" breakfast corner where breakfast and lunch are served at a great saving in labor.

Father, mother and the children are just as comfort ble as ever they were in a six-room house, and the housework is lessened by one-half.

The kitchen arrangement deserves special attention. The four-burner gas stove with its oven, the sink, ice chest, cupboards and drawers are all built of steel into one compact unit. Mother doesn't have to take a dozen steps to prepare a whole meal. She dumps the garbage into a chute that carries it outside the building. And remember, this is not an isolated instance. Thousands of families in our large cities are living in "folding" homes because the same economic conditions which force individual tamilies into smaller quarters, force owners to provide this sort of dwelling. If a man cannot rent an eight-room aprartment or house at a profit, he cuts it into two four-room apartments and pur-rom looms to each by the installation of clever built-in devices.

Many unique space-saving devices are now being used successfully. One would think, say, that it would be impossible to reduce the

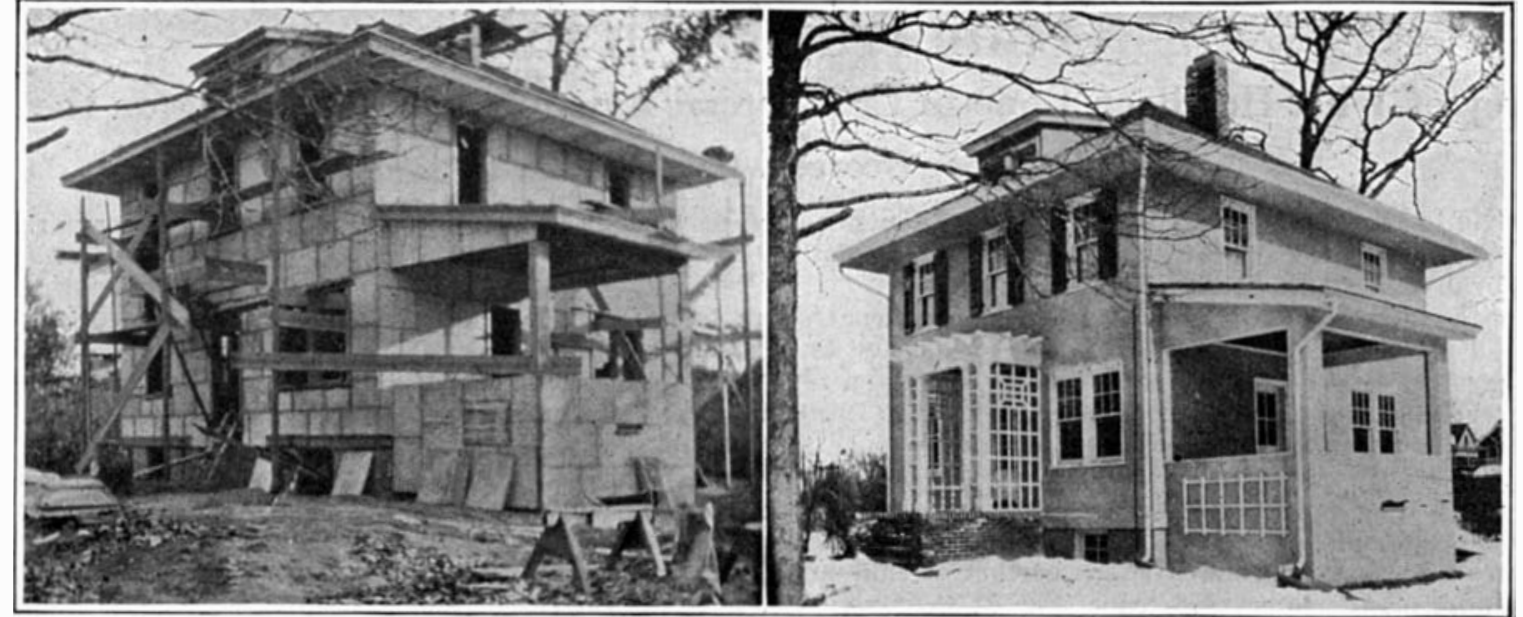

A form of construction that is steadily gaining favor: porous cement slabs during construction and as finished

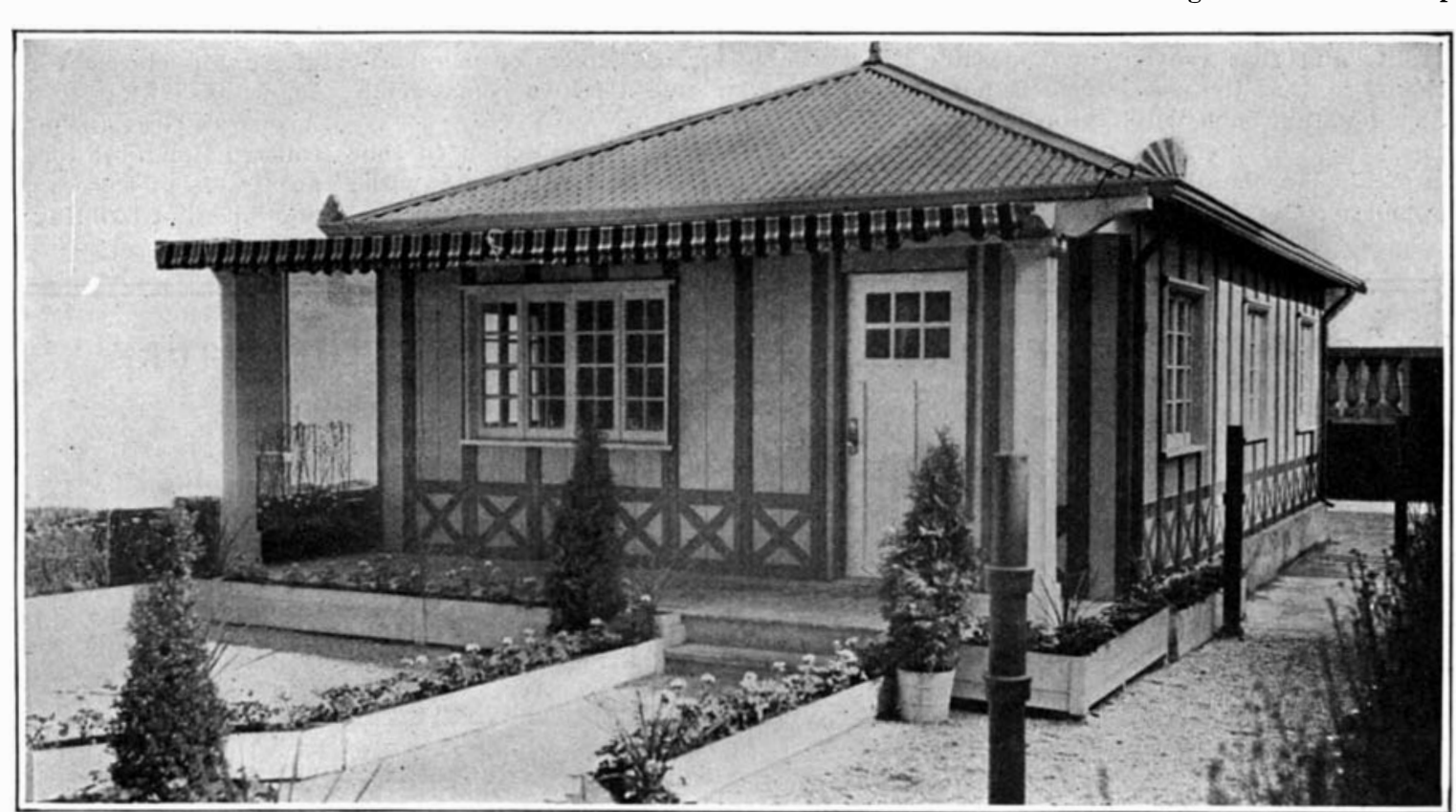

Fabricated steel house made up of standardized panels, which sells at a low cost and can be added to at any time fioor area occupied by a "man-sized" bath tub. But it has been done by making a deep well in one end of the tub, which is sunk beneath the floor. The bather then sits in an upright position, with the water around his shoulders, if he so desires. The deep basin is also

"What we are coming to," said William L. Murphy, perhaps the most successful inventor of space-saving devices, and head of a nationwide organization, "is actually a revolution of our ideas of what a home should be. And it has taken a mighty upheaval to are not easily turned away from the modes of living with which they have grown up.

"The idea of the small house in which every inch of space is useful, originated, or at least first gained prominence, in California where the housing problem is least acute, notably in Los Angeles and later San Francisco. The idea has moved eastward steadily until it is just gripping the great centers of population in the East. Why this should have been I cannot explain. It simply happened that the people of the west that the people of the new building ideas. Stucco, for instance, is just gaining prominence as a building material in the East, while in sections of California fully ninety per cent of the buildings are of stucco.

"But will people return (Continued on page 87 )

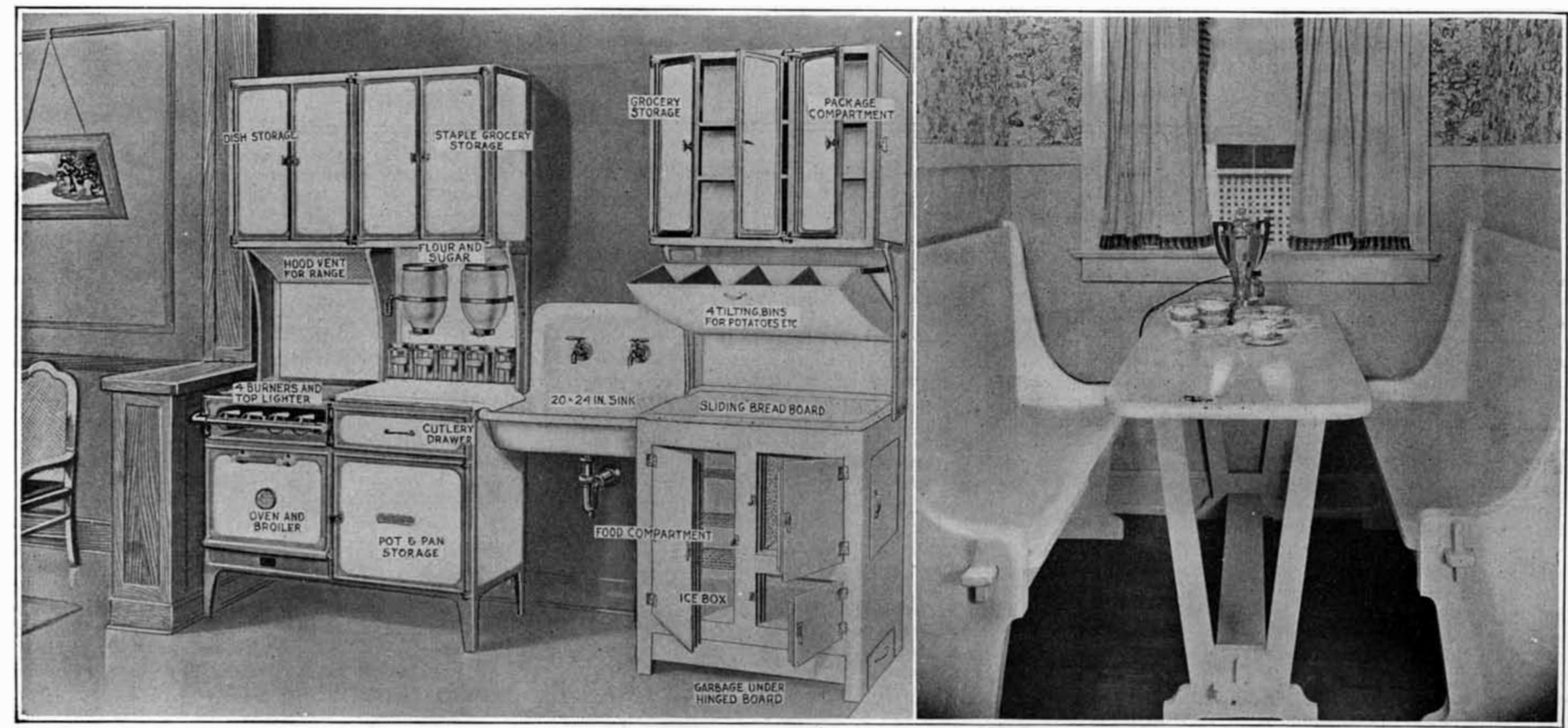

Left: Complete kitchen unit made of steel and in one piece, comprising stove, sink, dish storage, grocery storage, ice box and so on. Right: Breakfast and luncheon table and benches for the corner of the kitchen 


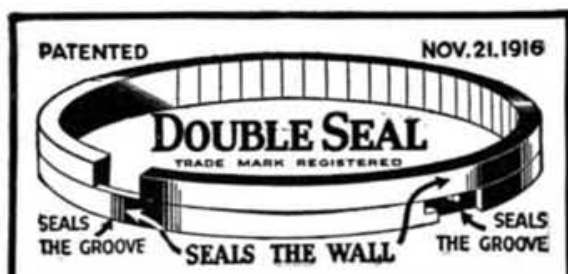

For Pep, Pickup and Power

\section{Double Seal Piston Rings}

All Sizes and Standard Oversizes carried in stock

at all our Sales Branches

double seal Ring Co. 2335 Michigan Ave., Chicago, 111. Branches in All Large Cities

For Gunsmiths, Tool Makers, Experimental \& Repair Work, etc.

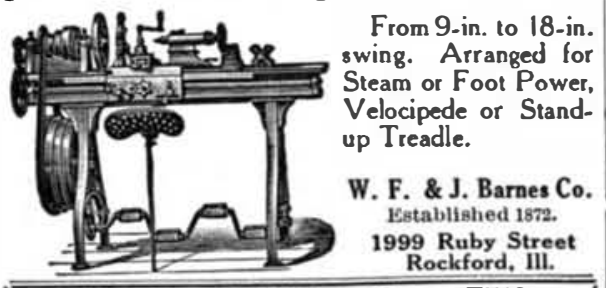

POWER BENDERS NEW MODELS $_{\text {MOD }}$

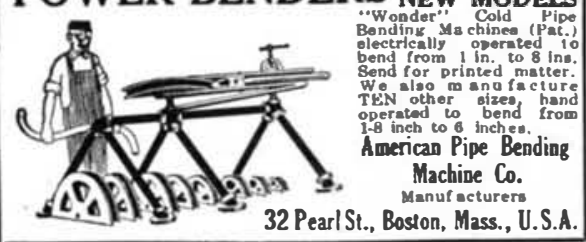

THESCHWERDTLE STAMP CO. STEL STANPS LETTERS \& FIGURES BRIDGEPORT CONN.

MAXIM SILENCERS For Rifles, Target Pistob, Exhaute, Air Com.

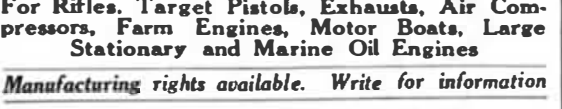
Manufacturing rights available. Write for

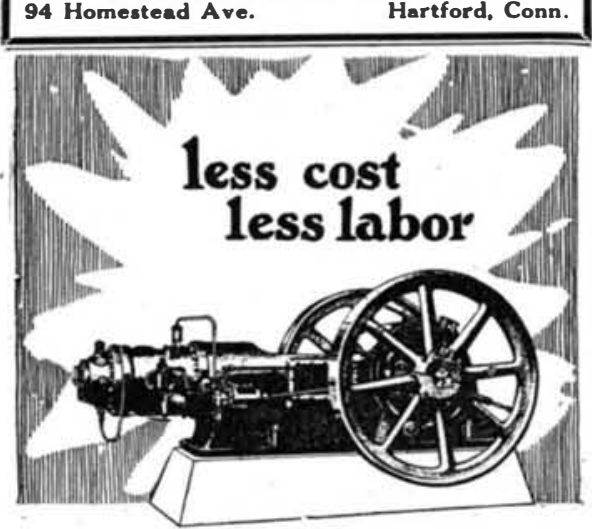

$B_{\text {problem wherever low cost and dependable }}^{\text {ESSEMER }}$ power is needed. A Bessemer installation operates on practically any grade of fuel oil. The tion alone, but in the prevention of costly shutance of coal storage. 15 to $180 \mathrm{H}$. P. Write fo

THE BESSEMER GAS ENGINE CO. 14 York Street,

Grove City, $\mathrm{Pa}$

BESSEMER OIL ENGINES
What Are Vitamines?

(Continued from page 76 )

Recently the discovery.has been made that the food richest in vitamines is yeast, of the sort we have always thought useful chiefly for making bread and beer. As early as 1852 an English physician named Moss reported the successful use of yeast as a medicine, but nothing came of it. man should take yeast, for instance, when affected with stomach trouble.

But in 1917 Dr. Philip B. Hawk r $_{r}$ of Jefferson Medical College, published the results of an intensive research which he had conducted with yeast, and gave new impetus to the interest of the medical profession. Since then a number of eminent and at least two of the largest hospital have loaned their facilities to the in have loane
gators.

It now appears that there was a very good reason for the English doctor's "foolish" notion, although he himself did not suspect it. Yeast contains in highly concentrated form the Vitamine $B$, an is particularly useful as a general co
tioner. Says Dr. Hawk in one report:

"In many of the cases which cam under our observation, the yeast treatment caused an improvement in the general physical condition of the patient quite unassociated with improvement of the symptoms of the particular disease in question."

Diseases which appear to improve from the yeast treatment include stomach troubles of all kinds, constipation, rundown and nervous conditions, loss of weight and appetite, boils, blackheads, and others. The improvement appears to come from the stimulative effect of the vitamines on the glands, especially those of the digestive system, combined possibly with some other unexplained properties of yeast.

Another significant conclusion was drawn from the feeding of yeast to rats "A scrawny lethargic animal, rather dwindling in size, with unsleek coat and evident malnutrition, will completely change its appearance and responses in a few days at most on a diet unchanged except for a tiny bit of yeast."

Undoubtedly many persons are suffering from a lack of sufficient vitamines. We use only the starchy part of our wheat, polish our rice, peel our vegetables and fruits and thus remove from our diet most of the vitamines. General health could without doubt be improved by replacing these lost elements. In this connection an eminent physician recently suggested that we eat at least a quarte of the skin of each orange because it is rich in vitamines.

Dr. R. Adams Datcher of the Division of Agricultural Biochemistry of the Minnesota Agricultural Experiment Station has experimented in the feeding of vitamines to farm animals.

"From the standpoint of the stock feeder as well as from the sociological standpoint," he says, "this work suggest two important things which merit emphasis: first, the question of diet in relation to sexual vitality, sterility, etc., and secondly, the importance of fresh green foods for all growing animals, especially poultry. We have cured limberneck in fowls by administering a vitamine extract prepared from wheat germ.

"It is very possible that the laxative action of many fruits, whole grains and bran is due in a measure to increased gland secretion brought about by the vitamine stimulation. As a result of our observations we wish to state tentatively that the actions of the organs of interna secretion are dependent upon the stimulating action of the vitamines. Whether this is in the nature of a nerve stimulant nuclear nutrient, or chemical nucleus of a hormone is of course a matter of speculation."

But we are interested here, not so much in the improvement of the genera health during normal lifetime as in this line of experimentation offers any hope that human life can be extended beyond the one-hundred-year mark which, so far, has been nearly always the absolute limit of life. Will it not be possible when the vitamines themselves; their effect on the glands, and the ter known, to live for two hundred or
ter five hundred years?

We may reasonably conclude from the cientific evidence already at hand that such a thing is plausible, at least. There seems to be no doubt that the potential immortality of the cells which compose the body has been established. There is growing volume of evidence, perhaps not onclusive, but making the probability very great, that old age is induced principally by the failure of certain glands which exert a mysterious but a very real influence upon all of the bodily tissues. Finally, the life and vigor of these glands seems dependent upon the mysterious food element, vitamines.

It is too soon to draw positive conclusions, but certainly the path to a vast new field of research is now cleared away which field may hold tremendous results for the human race.

\section{Home Building Simplified}

Continued from page 79)

to their six- and eight-room dwellings when economic conditions are again settled? I do not think so. I know of one case in the middle-west where a new old-style one. The new apartments have hree rooms, as against six in the older one. The quality of the buildings is about the same, but the three-room apartments rent for more than the neighboring sixrooms. I know personally that every one of the small but entirely modern and convenient apartments is rented all the the owner of the six-room suites has had trouble in keeping tenants:"

Aside from influencing the development of space-saving devices, which are revolutionizing interior arrangements, the housing shortage has also had the effect building materials and in the perfection of others.

In the Scientific A MERican of May 28th last there was described in detail the plan of Mr. Simon Lake for building small monolithic hollow-wall concrete units in centralized factories, the complete unit to be delivered on a special construction apparently overcomes previous objections to concrete homes in that it is damp-proofed, permits of an infinite variety of designs, and does not require the erection and tearing dow costly forms at the building site. ing unit which has recently made its appearance is of interest. In this case sheet ron is used in the construction which has many novel features. The chief feature of the house is that no nail or hole pierces the galvanized metal, so there are no points at which rust can attacks the metal. The outer walls are made of No. gage sheet steel, galvanized and inches wide, with a rigid pressed steel stud in the center of each section. These sections interlock with each other and the edges are held in place and reinforced by iron rods, which run through the sections lengthways. holding the roof and eaves securely in place, and being bolted roof also is of galvanized sheet steel and together with the outer walls forms a rigid water-tight all-steel structure. Inide this skell the finishing is done with ordinary woodwork. Walls and partitions are made of half-inch asbestos wallboard nailed to wooden studding and rafters As an added insulation against heat and sound all exterior walls are lined with

\section{U.S.Air Service}

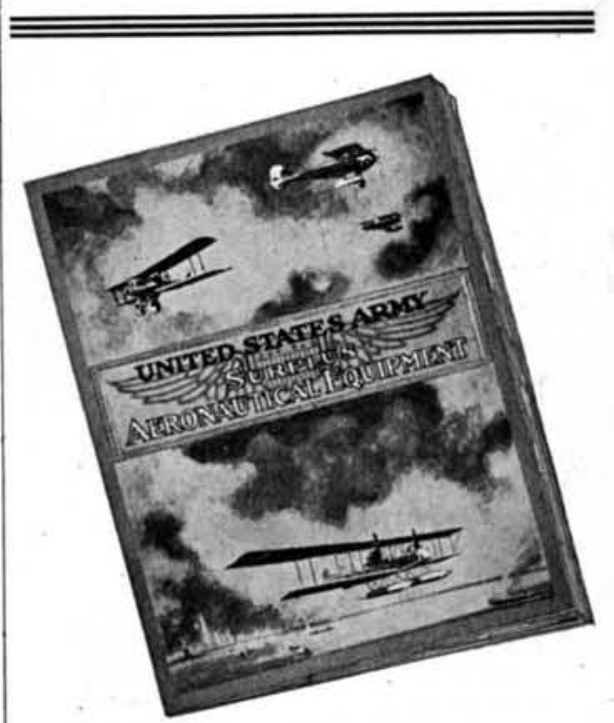

\section{If you are-}
a Flyer, a Student, an Instructor in Flying or in Construction, a Manufacturer;

You will be interested in the bargains offered by the War Department's great sale of Air Service surplus engines, planes, sea sleds, spare parts, and accessories.

Every conceivable bit of equipment necesService catalog which is sent to all persons interested. And the prices which are fixed are only small fractions of original cost of this quality material.

For an instance-a new engine at $\$ 100$ ! Twenty-four foreign and domestic makes to choose from. Some are readily converted for the values offered: planes at $\$ 100, \$ 150, \$ 200$ and up to $\$ 1000$.

\section{Write for the Catalog}

These are great buys, and you will find many others in the catalog. Look over the values offered, inspect the goods and place your order. At the low prices, these goods are moving fast. Get your orders in early. Write for the Catalog today. Address

Material Disposal and Salvage Division WAR DEPARTMENT

1616-K, Munitions Bldg., Washington, D.C.

\section{$\Longrightarrow$ प्रथा \\ UNITED STATES ARMY SUIRIPILUS \\ AERONAUTICAL EQUIPMENT}

We Will Make It Anything in a metal stamping or novelty pro
duced from any metal and finished in any color Waterbury Button Co., Waterbury, Conn.

\section{South Dakota}

State School of Mines

Rapid City, South Dakota Has just closed the best year in 1 ts history. Few Institu-
tlons have at Chele doorway sulch a wonderful outdoor
laboratory as the lilack H1lls region.

Drees are granted in Civil, Electrical, Mining. Metalurgical Engineering.

Expenses are low and much attention is given the Inthe advantages here provided. For catalog and book of 


\section{PATENTS}

IF YOU IIAVEAN INVENTION which you wish to patent you can
write fully and freely to Munn Co. for advice in regard to the best way of obtaining protection. Please
send sketches or a model of your invention and a description of the device, explaining its operation

All communications are strictly coning over a pur vast practice, estendenables us in many cases to advis in regard to patentability without any expense to the client. Our HandBook on Patents is sent free on request. This explains our methods,

terms, et.c., in regard to Paten
Trade Marks, Foreign Patents, etc.

SCIENTIFIC AMERICAN Contains Patent Office Notese, Decisiont of

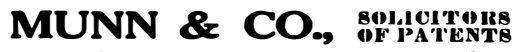
Woolworth Building.

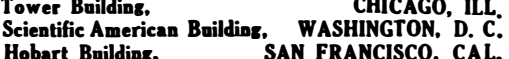

1.

Annual Subscription Rates

Scientific American (established 1845) one

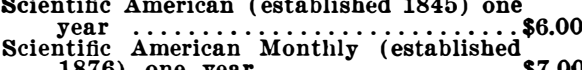

1876) one year . inited states and posses
Postage prepaid in United
sions, Mexico, Cuba and Panama.

Foreign Postage
Scientific American \$1.50 per
Scientific American

Scientific American $\$ 1.50$ per year additional.
ditional.

Canadian Postage
Scientifc American 75c per year additional.
Scientific American Monthly 36c per year addi-

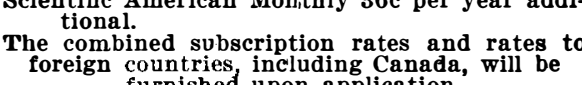
Remit by postal or express money order, bank
draft or check. BUSINESS OPPORTUNITY

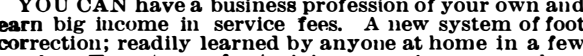
weeks. Easy terms for training; openings everywher
with all the trade you can attend to. No capital re BUSINESS OPPORTUNITY

SUBSTANTIAL manufacturing corporation want
capable ment to establist1 lranch and manage salesmen.
8300 to $\$ 2000$ necessary. Will allow expenses to Balti

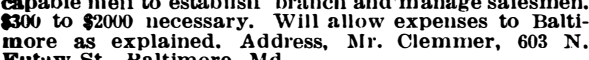
DIES AND PATENT FOR SALE Mill making cider without press. Widow of inventor
wants party to put on market. Sell dies; patent outright. FOREIGN STAMPS

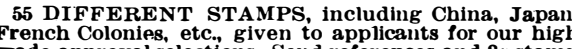
French Colonies, etc., given to applicants for our high
grade approval selections. Send references and $2 \mathrm{cstamp}$
to the EDGEWOOD STAMP CO., Dept. G, Milford, WANTED

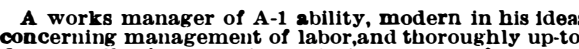
date on all other que metal products in a plant empleythg fifteen hundre salary required and references. Only thoroughly ex-
porienced men need apply. Box 131 , Scientific American BUSINESS OPPORTUNITY

wOULD like to get in touch with Aeroplane Manu-
facturers or others who might become interested and
are financially able to conduct Helicopter-Aeroplan are financially able to conduct Helicopter-Aeroplane
experiments. Guaranteed to be both interesting and
practical. Address E. M. Blacksher, P.O. Box 338,

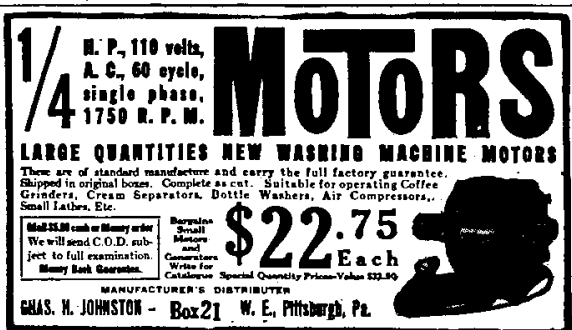

GAS, AIR, WATER, GASOLINE PUMPINC LEIMAN BROS. AIR PUMPS

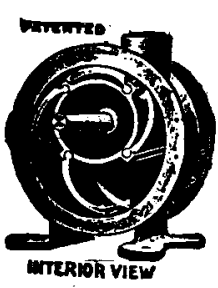
ROTARY-POSITIVE
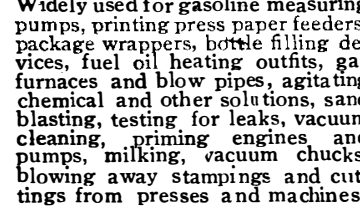

LEIMAN BROS. 81 Catalog No. 264-T-B6 WALKER ST., N. Y. complete house, 20 by 36 feet, containing around flues, back of kitchen ranges, four rooms and bath, is sold and erected complete with plumbing and lighting fixures for a little less than $\$ 2000$. The house may be extended lengthwise as desired in two-foot units, but cannot
made more than one story in height.

For the man who wishes to build a dis tinctive home from his own plans, there is interest in new building materials and in stucco construction.

One of the latest materials is a development of the asphalt shingle. In this case the asphalt base is made much heavier than usual and a coating of ground slate pressed on the surface. It is use
siding.

The latest development in stucco work is the recommendation from the Bureau of Standards, which is being generally accepted by builders, that when metal lath is used the customary wood "sheeting" be dispensed with and instead one coating of cement be stuccoed on the inside of the wall. This completely imbeds the metal lath in the cement, protecting it from corrosion; makes the wall more fire-proof ; and gives other desirable qualities. Insulating paper is nailed on the inside studding and over this are placed the furring strips, to which is nailed the expanded metal lath for the inside plaster finish. This method differs radically from standard practise and the requirements of many city building codes, which call for a solid board sheeting under the outside stucco; but it is backed der the outside stucco; but

\section{y scientific investigation.}

A Newark, N. J., inventor has placed holds the promise of remarkable results It is in the form of slabs of inch-thick porous concrete, nearly as light and as strong as wood, which are nailed directly to the studding of the house. Only two coats of stucco are then required to finish the

The porosity of the concrete is secured in a most ingenious fashion. Small pellets of parafin or some similar material are mixed with sand and portland cement and the mixture spread in slabs over wire mesh reinforcing and allowed to set for. a day and a half. Then the slabs are placed in an oven and subjected to a high degree of heat. The parafin is melted and driven off through the pores of the concrete, the fumes caught and condensed by distillation and used again in the form of pellets, and strange as it may seem, this heating does not affect the structure of the concrete but merely interrupts the setting process until the slab again cools off. The product is surpristhe only similar product now on the market is a light concrete manufactured by a Belgian firm, in which sawdust is an ingredient.

While it may appear that this method would make the slabs prohibitive in cost, the maker claims the finished building, because the labor item is lower, costs of stucco working. It is claimed that the insulating qualities of the porous wall are very marked.

A number of patented stucco mixtures have also made their appearance on the market, and qualities are claimed for each. Such mixtures are said to be superior to ordinary cement stucco and the material is entirely damp-proof,
elastic, desirably colored, and so on.

Since houses are at a premium more attention is being paid to making them fireproof. A scheme has been devised by a number of manufacturers of metal lath for rendering an ordinary frame building so nearly fireproof that it would be hard erection of firestops at all vulnerable points, as under all bearing partitions and
pointion of stud exterior walls, ceilings over heating lan adds

All in all, the man who has waited to build his home until conditions are more settled can profit by some very remark able housing developments for his

\section{Tomorrow's Airships}

(Continued from page 80 ) airship of $31 / 2$ million cubic feet, which can be constructed in England without existing sheds. This ship is calculated
existion of the to have a gross lift of 105 tons and a disposable lift of 68 tons. The estimated speed at full power is 75 m.p.h. and the endurance, carrying 15 tons of pas-
sengers and freight, 80 hours or 1800 senger
miles.

The proposed route to New York from London is via Portugal and the Azores, to advantage of the better weather con the time taken 60 hours. The return journey would be made by a direct crossng of some 3000 miles and time taken would be 50 hours.

With four airships working it is anticipated from an examination of weather be on 300 days in the year, and that 200 rossings could be maintained. Fifteen tons would admit of 140 passengers and their luggage to be carried, or 50 passengers and 10 tons of mails.

\section{Synthetic Agriculture}

(Continued from page 81 )

What used to be called theory has portance, so among the practices derived tures, but with soil from a nearby field which had borne a leguminous crop the
previous year. These bacteria spreading previous year. These bacteria spreading lowly through the soil should be harthe burning sun. This insures a good first leguminous crop where oth

The climate has not been studied enough
foures had often to be recorded. up till now in connection with crop production. It plays an important part,
in so far as it allows the obtaining of higher crops, when full advantage taken of its action.

Machinery and implements are chose on the principle that only one type is best suited to the work it has to perform
Deep working of the soil is one of the great assets of synthetic agriculture. Sometimes it is necessary to proceed gradually but the final results are: better aeration; humus, bacteria and feeding eleproved water supply, deep rooting encouraged, crops suffer less from heat, and closer cropping can be indulged in.

Subsoiling has a marked effect on most of the crops; harrowing and especially sowing are more often done too shallow depth is seldom attained.
dem too deep and the

Rolling and hoeing have most remarkable effects; they are not used to the full extent justified by their usefulness. For instance, in summer a crop is brought up rapidly by rolling, but once the tap root
down, the surface must be broken to check down, the surface must be broken to check
evaporation. The effect of hoeing has bee ranslated by several people into something tangible like: once hoeing equals a shower, but twice equals a dressing; but till the dressing value is often left aside.

\section{Transporting Electric Current} (Continued from page 84)

final position. The gin pole is usable where the weights do not become considof shear legs may be substituted for the of shear legs may be substituted for the
ordinary gin pole. These are two long around stair walls and under stairs. The

In this case the figures are based on an proved to be of the utmost practical imnewly reclaimed land, not with pure cul-

poles so set as to lean toward each other, row isosceles the sides of a tall and narside poles may be secured to a horizontal member at its ends. This complete triangle may then be used much after the manner of the single gin pole.

It is highly important that all preparations be completed by the moment actual hoisting to position begins. It seems that accidents during the actual may easily drop when erection has reached a point where the tower is at a 45 degree angle. If the tower slips at the location of the "hinge," any amount of trouble may ensue, not to say loss of life or limb. A good deal of attention has been given to the matter of this "hinge." One of the successful devices ployed as the axle of rotation. The tower will naturally have two legs on the ground. Over the feet are secured shoes made of angle bars. These shoes are so shaped as to fit well and permit of being bolted to the foot through the regular rivet holes. Each shoe is provided with neath the sole. say, five inches in diameter. When the shoes have been bolted in place, the bottom legs of the tower will have two loops, one to each leg, forming, as it were, prolongations of the legs. A 4-inch iron pipe is passed through the two loops. This pipe is of a length to permit, say, 1 foot to project beyond each loop and to to turn during the erection operation. In order to prevent the pipe itself from slipping sideways on the ground, a loop at the end of a steel cable is passed over each projecting end, and the cable itself is secured at a convenient point on the side from which slippage, if it occurs, is to be expected. Pins driven into the of anchorage.

When a tower is being erected by the shear-leg method, it is important that the erecting operation be not permitted to proceed too far. It is said that many towers have dropped because of having been pulled too far over. To guard head of the wire rope is attached to the the side from which movement is to take place. Naturally, this line, which is to be used substantially as a guy rope, must yield to allow erection to go on. But it must be carefully controlled, and there must be sufficient resistance to prevent the erecting pull from going too far. Fortunately, the maximum resistance does not 